\title{
Corporate Training of Yakutia Teachers to Apply Methods of E-Learning
}

\section{Capacitación corporativa de maestros de Yakutia para aplicar métodos de aprendizaje electrónico}

\author{
Maxim Anatolyevich Sorochinsky* \\ North-Eastern Federal University, Yakutsk, Rusia \\ ORCID: https://orcid.org/0000-0002-4651-3384 \\ Elizaveta Afanasevna Barakhsanova \\ North-Eastern Federal University, Yakutsk, Rusia \\ ORCID: https://orcid.org/0000-0003-3327-8773 \\ Elena Zotikovna Vlasova \\ North-Eastern Federal University, Yakutsk, Rusia \\ ORCID: http://orcid.org/0000-0001-7356-5019 \\ Mikhail Semenovich Prokopyev \\ North-Eastern Federal University, Yakutsk, Rusia \\ ORCID: http://orcid.org/0000-0002-7565-8902 \\ Arkady Eduardovich Burnashev \\ North-Eastern Federal University, Yakutsk, Rusia \\ ORCID: http://orcid.org/0000-0002-1894-4216
}

Recibido 12-12-19 Revisado 12-01-20 Aprobado 14-03-20 En línea 16-03-20

*Correspondencia

Email: MaksimSorochinsky@yandex.ru

\section{Citar como:}

Sorochinsky, M.A., Barakhsanova, E.A., Vlasova, E.Z., Prokopyev, M.S, Burnashev, A.E. (2020). Corporate Training of Yakutia Teachers to Apply Methods of E-Learning. Propósitos y Representaciones, Doi: http://dx.doi.org/10.20511/pyr2020.v8n3.486

(C) Universidad San Ignacio de Loyola, Vicerrectorado de Investigación, 2020. 


\section{Summary}

Teacher training can assist in initiating digital changes in education. However, to achieve this, the training should use leading examples from the field of digital education solutions and technologies, while university and school educators should be trained to apply them in their work and to create high-tech educational startups in the field of e-learning. The goal of this study was to increase the professional competencies of teachers by conducting a corporate course that would prepare the teachers of the university in Yakutia to apply e-learning methods. The article demonstrates that the introduction of e-learning at the university is an important comprehensive process that implies transformation of all education components under the influence of modern technologies. Its practical implementation requires changing the goals, organizational forms, and technologies of educational activities in line with new technologies as well as the development of productive strategies for integrating the created innovations into the traditional learning process. For this purpose, the authors conducted a sociological study that helped identify the main problems associated with this type of training (for example, developing a course is time-consuming and a lack of required skills to develop courses). Based on the obtained data, the authors proposed a corporate course for university teachers on the creation of educational content for e-learning. It was shown that when applying new types of educational activities, teachers should combine traditional and new technologies, which contributes to the innovative training of teachers to meet the requirements of the digital society. This study focused on practical issues, since the research results were implemented in the work of the North-Eastern Federal University (NEFU), the base of the research. The results can be used when training teachers to apply e-learning methods in other educational institutions.

Keywords: Corporate Training; Refresher Training; E-Learning; Education; University; Teachers.

\section{Resumen}

La capacitación docente puede ayudar a iniciar cambios digitales en la educación. Sin embargo, para lograr esto, la capacitación debe utilizar ejemplos líderes del campo de las soluciones y tecnologías de educación digital, mientras que los educadores universitarios y escolares deben estar capacitados para aplicarlos en su trabajo y crear nuevas empresas educativas de alta tecnología en el campo de la e- aprendizaje. El objetivo de este estudio fue aumentar las competencias profesionales de los docentes mediante la realización de un curso corporativo que prepararía a los docentes de la universidad en Yakutia para aplicar métodos de aprendizaje electrónico. El artículo demuestra que la introducción del e-learning en la universidad es un proceso integral importante que implica la transformación de todos los componentes educativos bajo la influencia de las tecnologías modernas. Su implementación práctica requiere cambiar los objetivos, las formas organizativas y las tecnologías de las actividades educativas en línea con las nuevas tecnologías, así como el desarrollo de estrategias productivas para integrar las innovaciones creadas en el proceso de aprendizaje tradicional. Para este propósito, los autores realizaron un estudio sociológico que ayudó a identificar los principales problemas asociados con este tipo de capacitación (por ejemplo, desarrollar un curso lleva mucho tiempo y la falta de habilidades necesarias para desarrollar los cursos). Sobre la base de los datos obtenidos, los autores propusieron un curso corporativo para profesores universitarios sobre la creación de contenido educativo para el aprendizaje electrónico. Se demostró que al aplicar nuevos tipos de actividades educativas, los docentes deben combinar tecnologías tradicionales y nuevas, lo que contribuye a la formación innovadora de docentes para cumplir con los requisitos de la sociedad digital. Este estudio se centró en cuestiones prácticas, ya que los resultados de la investigación se implementaron en el trabajo de la Universidad Federal del Nordeste (NEFU), la base de la 
investigación. Los resultados se pueden usar al capacitar a los maestros para aplicar métodos de aprendizaje electrónico en otras instituciones educativas.

Palabras clave: Entrenamiento corporativo; Cursos de Actualización; E-learning; Educación; Universidad; Maestros

\section{Introduction}

At present, the education system of the Russian Federation is rapidly improving and developing in various areas, which indicates the need for the continuous training of educators. Informatization is central to the development of almost all spheres of human activity in the twenty-first century, including education. The informatization of education implies not only the introduction of something completely new (such as technologies, methods, and techniques) but also primarily indicates compliance with the conditions of the modern information and communication environment and meeting the social requirements of the modern education system (Marchyuk, 2013).

Nowadays, teachers often have to use modern information technologies, such as electronic courses, multimedia content, access to the Internet, and educational and diagnostic programs. These are typically considered the most effective learning tools in modern education. However, the development of materials for the e-learning environment is a complicated task, as it requires a sufficient level of qualification and can be successful only when one considers the specifics of this form of learning and the preparation of teachers in implementing it.

One of the tools for preparing teachers for the implementation of e-learning can be corporate training - an integral part of corporate education. During corporate training, an employee improves their professional competencies, so one can consider corporate training as one of the components of corporate education, or corporate education in a narrow sense. Corporate training implies that employees of an organization can master certain competencies in some specified field (in this case, e-learning). They are seen as actors who not only gain knowledge and skills but also can transmit and disseminate this information.

The term e-learning was first used (in a professional environment) "in October 1999 in Los Angeles at the CBT Systems workshop" (E-Soft Development, 2016). In Russia, this concept was legally defined only in 2013 with the adoption of the new law "On Education in the Russian Federation" and replaced the widely used concept of distance learning. However, all the accumulated experience in distance learning was integrated into this newer conception of elearning.

The global trends in e-learning development are presented in Figure 1, which shows the dynamics of the financial turnover in the e-learning market in general and in the independent elearning market (in billions of dollars). 


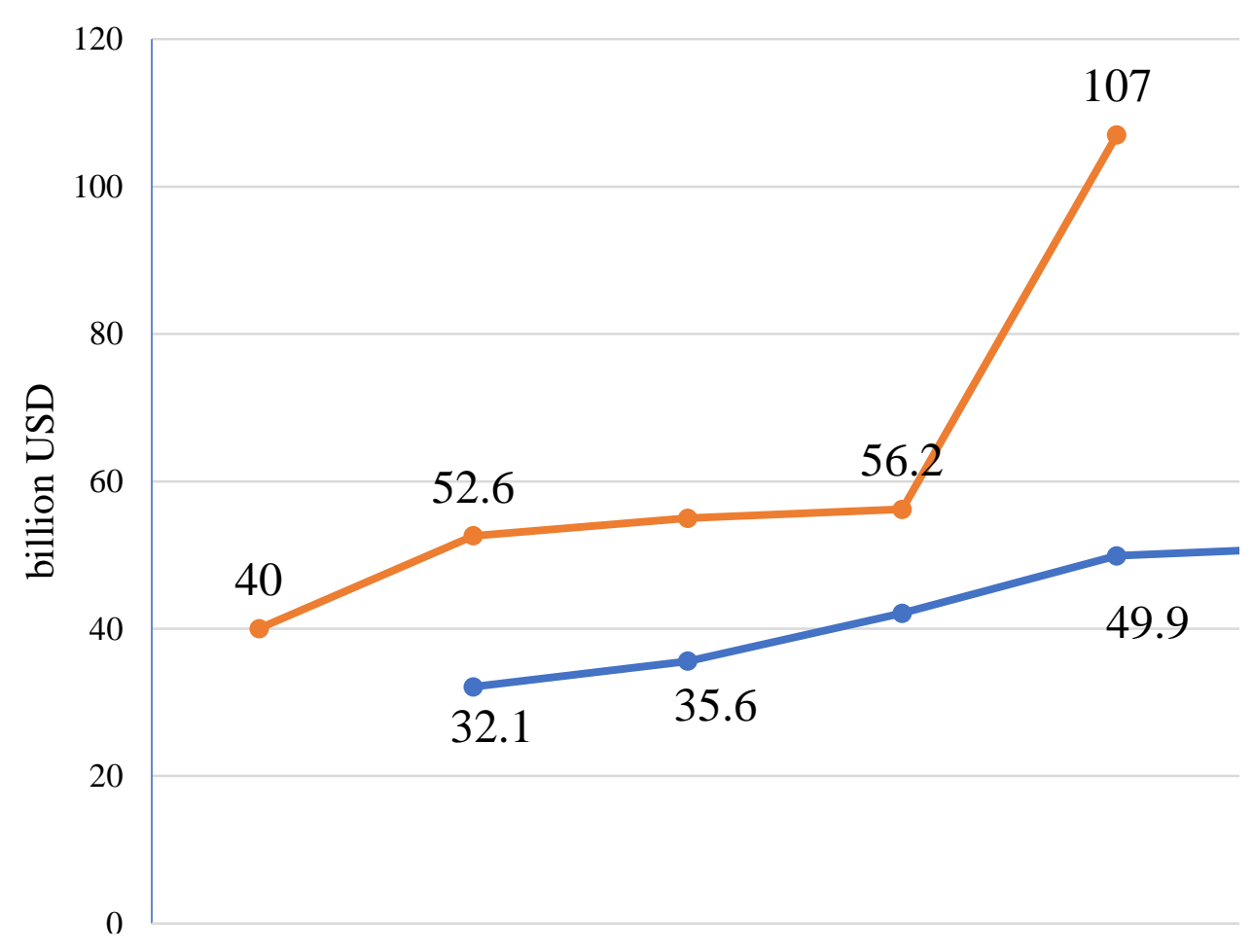

Figure 1. The total turnover of the global market for e-learning and self-study (USD billions).

The research goal was identified in line with this data: to theoretically substantiate and develop a corporate course for training university teachers in Yakutia to use e-learning. To achieve this goal, we set the following objectives:

- To analyze research publications and experience on the implementation of corporate training and the role of e-learning in the education system;

- To identify problems that the teachers of the North-Eastern Federal University (NEFU) have in implementing e-learning;

- To create a teacher training course "Technologies for the Development of Electronic Courses on the Example of the iSpring Suite".

E-learning is rapidly developing and gaining popularity in Russia despite a significant lag behind the countries that lead in this area. Here we should note that creating materials for the elearning environment is a challenging task that requires sufficient qualifications and can be successful only when it reflects the specifics of this form of training and teachers are ready for its implementation.

Business development in a market economy imposes new requirements on the education system. While higher or secondary vocational education used to guarantee success in one's occupation, nowadays, so-called "useful knowledge" is in more demand than academic knowledge, since it is aimed at the end result and brings economic benefits. This, in turn, increases the demand for specialists with this type of knowledge. A huge advantage and a competitive factor for any company are its employees, while the level of the company depends on the competence of its staff. For a company, it is becoming increasingly important to not only 
improve the qualifications of its employees, but also to train them in the specific knowledge and skills that are required for a particular position. In constantly developing companies, the training of a new type of staff requires new forms of education, one of which is corporate training (Sorochinsky, 2016).

Businesses have long actively made use of corporate education and corporate training, but they are becoming more common in many other state and social spheres. One of the main examples is in the state programs with the professional development of educators (school and university teachers, educators, etc.). Corporate education and corporate training are the terms more commonly used for commercial organizations and enterprises. In social and public spheres, more frequently used terms are staff development or professional training, which are an integral part of corporate training.

\section{Literature review}

The term "corporate training" can be defined in myriad ways. As a case in point, M. A. Korobkina distinguishes two approaches: the traditional approach; and the approach in market conditions. Under the traditional approach, the emphasis is placed on the content of training: "in this case, the trained staff has a passive role, with a more significant role of theory. The market approach, in turn, highlights the process of knowledge transfer, subsequent to which the trained staff takes an active position, with practice being the key element. However, in today's day and age, the most relevant approach in corporate training is "learning by doing," which is an alternative to traditional learning" (Korobkina, 2013). Notably, this approach implies learning in role-plays, solving problems, performing creative tasks, and gaining relevant knowledge, with group work as its main element.

J. Cole opines that "a systematic approach to training and education implies logical coordination of the activity beginning when one clarifies the policy and resources required for it, and next assesses the need for training. After this, self-training is conducted, followed by an assessment of the results. The project-based approach is proactive: the management makes a tactical decision to train staff, so that in the near future their competence can meet emerging challenges" (Chernova, 2015). Under a problem-situational approach, training acts as a tool for developing skills that help resolve old problems which are often difficult for employees to tackle.

According to the analyzed research papers, corporate training implies mastering certain competencies of the company's employees in a chosen field (in this case, e-learning) and considering the staff as actors who not only accumulate knowledge and skills in a systematic manner, but also transmit and disseminate them.

International and Russian scientists alike have considered the implementation of elearning and its various facets. It has been observed that international researchers are often more interested in developing and implementing methods for training specialists, including teachers, to use e-learning (Skoulikari, 2015; Min et al., 2016). These studies examine the implementation of e-learning systems as a constituent of individual and group learning, including courses that are available in both mobile environments and devices.

Some extant publications discuss several aspects of training future teachers in order to apply various teaching technologies (Min et al., 2016), as well as to identify changes in the educational needs within innovative electronic information and educational environments. (Schulz, 2014) Others meanwhile consider the economic and market coefficient, thereby enhancing the motivation to education (Clark, Mayer, 2016), the ways of delivering the 
educational content, and deciphering the nature of interaction between teachers and students along with its stimulation (Allen, Seaman, 2013).

Based on the analytical reports of Global Industry Analysts, it can be concluded that "the total global turnover of the e-learning market in 2010 amounted to USD 52.6 billion, with an increase of $32 \%$ (USD 40 billion) compared to 2007. In 2013, e-learning is an industry with the sales volume of USD 56.2 billion." In 2015, an analytical company registered a growth of up to USD 107 billion (Global E-learning Market ..., 2016).

Leading scientists pay special attention to e-learning: for example, V. Bradac and B.A. Walek (2017) emphasize the potential of e-learning in mastering foreign languages. S. Martin and I.M. Alvarez Valdivia (2017) explore the behavior and feedback during online classes. M. Kurucay and F. A. Inan (2017) study the effect of students interaction on their satisfaction with the quality of undergraduate education in an online course. Others (Clark, Mayer, 2016; Yang et al., 2017) explore the issues of student and teacher satisfaction with e-learning systems, various aspects of changing educational needs in innovative electronic information and educational environments. In addition, researchers analyze the potential of using artificial intelligence methods in e-learning (Camilleri, 2017; Jiang et al., 2016).

Today, the term "e-learning" seems to be the most accurate, as it is gradually replacing the concept of distance learning and appears in new amendments to the Federal Law "On Education," which confirms its relevance and justifies its use in this context. The theoretical basis of the study was the work of Russian authors in the field of adaptive e-learning (Vlasova, 2018) and information technology (Barakhsanova, 2017). Therefore, training all future specialists, and especially educators, to apply e-learning methods is mandatory, and this has long been proven by the global experience.

Russian researchers (Barakhsanova et al., 2016) point to the insufficient development of e-learning in the North-East of Russia, including Yakutia, and claim that e-learning is only beginning to develop in the Russian Federation, although the pedagogical community is aware of its prospects and is taking measures to reduce the lag in this area.

\section{Method}

A sociological study was conducted on the basis of the North-Eastern Federal University and involved 13 faculties and institutes. The general population was the teaching staff of the NEFU (101 people). The survey was conducted by accidental sampling using Internet technologies as a Google form with the hyperlink distributed through social networks and WhatsApp service, as well as by personal interviews. Despite the fact that the method of accidental sampling has certain drawbacks, the data obtained in the survey are quite representative.

According to the sample size calculator, for a population of approximately 1600 people, a sample of 101 people will correspond to a confidence level of $97 \%$ with an error of $10 \%$. In this study, we applied the methods of secondary data analysis, comparative analysis, and personal interviews. The questionnaire consisted on two blocks of questions: the first block had eight questions directly related to the subject of the study (identifying problems teachers had when implementing e-learning) and the second block consisted of four questions that would provide a social portrait of the respondents. Based on the obtained data, we developed and introduced a corporate course for university teachers, which aimed to increase their competence in the field of developing educational content for e-learning. 


\section{Results}

In this research, we used the data on the structure of the NEFU to develop the organizational structure of the university departments that are responsible for advanced training of the teaching staff. It was necessary to train the teachers to present the educational materials in Moodle Learning Management System (LMS) and to create training courses in the e-learning environment. Since 2015, the Yakut Global University has been implementing the teachers training course "Using e-learning technologies (on the example of Moodle LMS)." This course can be done both full-time (with elements of e-learning) and through distance learning technologies.

To assess how well the teaching staff knows the programs and systems required for elearning, as well as problems they encounter in their implementation, we conducted a survey with a title "Identification of problems associated with the use of e-learning tools." According to the results of the survey, the age structure of the respondents included various groups, which undoubtedly had a positive effect on the reliability of the study:

- $54.5 \%$ of the respondents were from 36 to 50 years old;

- $24.8 \%$ were from 20 to 35 years old;

- $16.8 \%$ were from 51 to 60 years old;

- $2.2 \%$ were 66 or older.

Regarding the academic credentials of the respondents: $52.2 \%$ had a degree of a Candidate of Sciences, $43.5 \%$ held no postgraduate degree, and $4 \%$ were Doctors of Sciences. The survey covered 13 different faculties and institutes. Next, let us analyze the main block of the questions. The survey data showed that more than a half of the respondents, namely $88 \%$ of the NEFU teaching staff, used elements of e-learning or distance learning technologies when conducting classes (fully or their fragments).

The majority of the respondents, namely $87.9 \%$ of the NEFU teaching staff, believed it necessary to use e-learning and distance learning technologies in the educational process, whereas $11.1 \%$ did not agree with this opinion. The majority of the respondents, namely $60 \%$, found it difficult to work with the electronic training system (Moodle LMS) or to develop courses. Next, we asked the respondents a clarifying question regarding the difficulties encountered when working in the framework of e-learning (Fig. 2). 


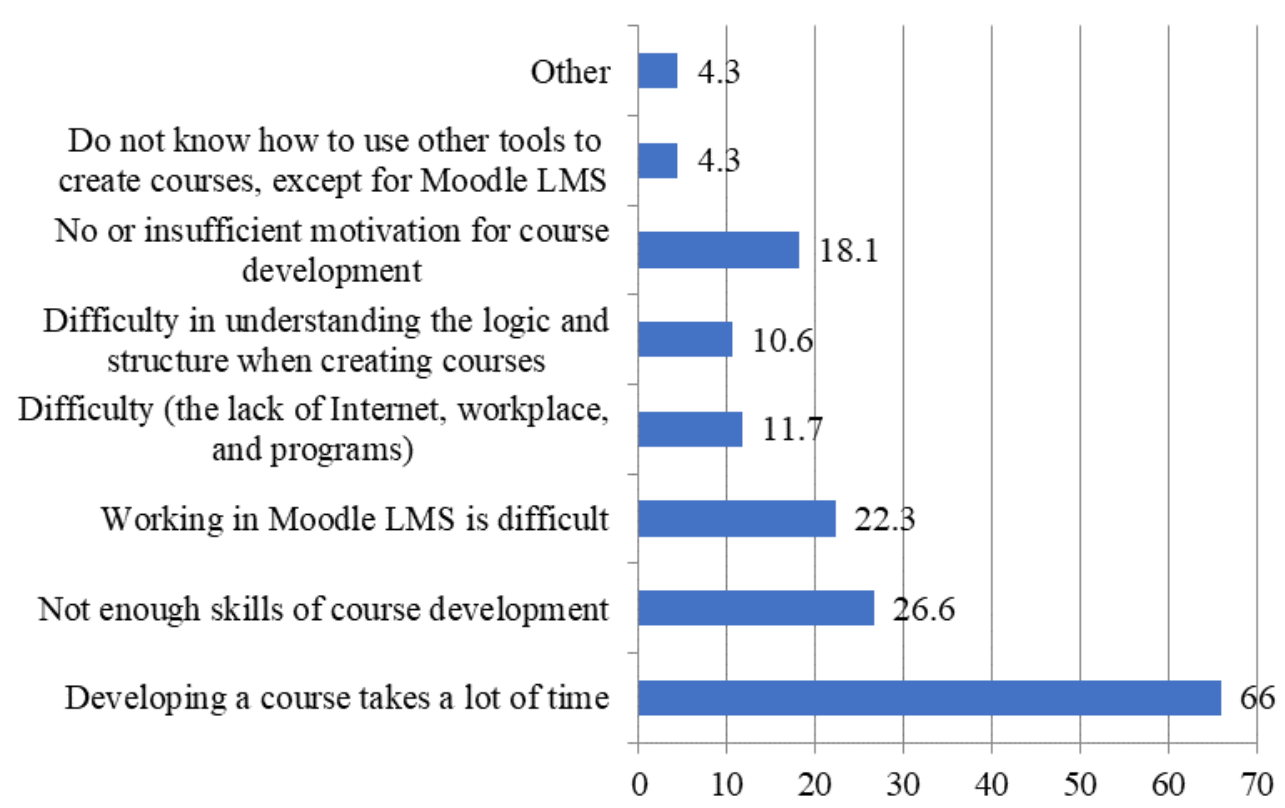

Figure 2. Respondents' assessment of difficulties associated with the application of e-learning, $\%$

The data presented in Figure 2 show that for most of the interviewed teaching staff in the NEFU the main problem was the considerable amount of time spent on course development. Another significant aspect was the lack of skills required for developing courses (26.6\% of the respondents). Considering the results of the survey among the NEFU teaching staff, it was necessary to develop a refresher course for teachers. The performed analysis enabled us to identify certain problems. Since most teachers were familiar with Moodle LMS, we decided to develop a refresher course for the Yakutsk Global University of the NEFU on the topic "Technologies for the development of electronic courses on the example of iSpring Suite." This course could solve the problems associated with the lack of time for courses development and to provide the teachers with the skills they needed.

The development of the course was divided into several categories (stages). Each of these could be used independently or in combination with each other, and the teacher could combine the necessary elements. The refresher course was developed in accordance with the survey results and aimed to familiarize the university teachers with technologies for creating electronic courses on the example of iSpring Suite.

\section{Discussion}

Many international and Russian researchers explore the concept of corporate training. For instance, William Ouchi (2017) formulated Theory Z - one of the theoretical prerequisites for the emergence of corporate training and the creation of corporate universities. Studying the Japanese management system, William Ouchi concluded that employees' motivation should come from the values of the "production clan," that is, an enterprise as one large family, one kin. In addition to building perfect business processes, it is crucial to properly select and train personnel.

Today, there are many definitions and synonyms for "corporate training": corporate education, personnel training, staff training, advanced training, employees training (retraining), etc. In addition, corporate training combines several types of training: professional training, staff training, and personnel training. Each of these areas has its own specifics (Slobodsky, 
2013). To identify the key components of corporate training, let us consider its main definitions and interpretations.

Due to a large number of concepts, terms, and definitions associated with corporate education and training of employees in a company, these concepts are often confused or used interchangeably, which occurs unintentionally. For instance, T. A. Khagurov, in the article "On lifelong education," says that "the concepts of "education", "training" and "preparation" are confused. Education is what you receive once and for all, in contrast to the training that nowadays should be done at regular intervals. Education is the comprehensive development of people - the formation of their intellectual, spiritual, moral, volition or physical qualities. Education ensures that later people can independently develop both themselves and their knowledge or skills" (Khagurov, 2012).

Another element of corporate training is the development and improvement of new professional knowledge and skills necessary for working in a company. In turn, professional training is an integral part of corporate training. According to M. Armstrong (2004), the concept of vocational training "takes a clear form and systematically changes one's behavior by forming new skills, which occurs as a result of training, instruction, development, and systematic practical experience." This approach to vocational training by changing one's behavior complies with current trends in personnel management.

The concept of e-learning is defined by its potential. It is seen as a "type of training that provides quick access to resources and services, their exchange, and productive joint work of the participants in the educational process. It is actively used by many companies and educational institutions, can increase efficiency, and save training time. Teachers and researchers are encouraged to introduce innovative methods, technologies, and tools for the development and application of e-learning solutions. That is why the scope of e-learning is constantly growing. Today, all the advanced educational systems throughout the world are guided by its principles" (Vlasova, 2014). Furthermore, when training future specialists, especially educators, e-learning is a necessity that has long proved its significance all over the world.

\section{Conclusion}

In this research we performed a theoretical analysis of the publications and the available experience on the implementation of corporate training and the role of e-learning in the education system. Based on the study of research papers on the issue, we concluded that elearning is developing rapidly in the field of education and becoming more popular in Russia. According to experts, the e-learning market in Russia is expected to grow annually by $20-25 \%$ (Overview of the World..., 2016), despite the significant lag in this area from the United States and European countries.

We considered and analyzed the system of staff development at North-Eastern Federal University. Based on this, we developed a structure for advanced training of the NEFU teachers. The Yakutsk Global University of the NEFU will play the main role in the advanced training of teachers using e-learning. This organization carries out the main functions of preparing the university staff for the implementation of e-learning.

To identify problems university teachers encounter when implementing e-learning, we conducted a survey titled "Identification of problems related to the use of e-learning tools." The survey was conducted by accidental sampling based on Google services by sharing hyperlinks through social networks and WhatsApp, as well as by personal interviews. Having studied the survey results, we came to the following conclusions: 
- The majority of teachers $(88 \%)$ include elements of e-learning in their classes; and

- $60 \%$ had difficulty working with the electronic learning management system (Moodle) while developing courses.

- The respondents named the following main difficulties associated with elearning: 1) $66 \%$ - developing a course is time-consuming; 2) $26.6 \%$ - a lack skills required to develop courses; 3) $22.3 \%$ - difficulties when working with Moodle; 4) $18.1 \%$ - A lack of motivation to develop a course.

According to the survey results, we considered it viable to develop a refresher course for the NEFU teachers. Most teachers were already familiar with the Moodle LMS environment, that is why we proposed a refresher course for the Yakut Global University of the NEFU titled "Technologies for the development of electronic courses on the example of iSpring Suite," which was designed to solve problems associated with the lack of time to develop courses and make up for the lack of skills required for this. The course consisted of six modules, and each of them was designed to familiarize teachers with certain functional features of iSpring:

1) Introducing iSpring Software;

2) Building a course based on a PowerPoint presentation;

3) Creating audio and video materials for the course;

4) Developing interactive tests and surveys;

5) Creating interactive blocks and active elements;

6) Course publication.

The convenient and intuitive interface of iSpring software significantly reduces the time required for creating a comprehensive course. This study focused on practical issues as its results were used in the work of the Yakut Global University of NEFU in the form of:

1) A survey among the NEFU teaching staff on the topic "Identification of problems associated with the use of e-learning."

2) A course on iSpring software as part of a professional development course for teachers on the topic "Identification of problems associated with the use of elearning."

The study results allowed us to improve the refresher courses for teachers and to identify the main problems that they face when developing courses for e-learning.

\section{References}

Allen, E., Seaman, J. (2013). Changing Course: Ten Years of Tracking Online Education in the United States. Babson Survey Research Group and Quahog Research Group, LLC.

Armstrong, M. (2004). Human Resource Management Practice. St. Petersburg: Peter. 
Barakhsanova, E.A., Savvinov, V.M., Prokopyev, M.S., Vlasova, E.Z., Gosudarev, I.B. (2016). Adaptive education Technologies to Train Russian Teachers to Use E-learning. IEJME-Mathematics Education, 11(10), 3447-3456.

Barakhsanova, E.A., Vlasova, E.Z., Golikov, A.I., Kuzin, Z.S., Prokopyev, M.S., Burnachov, A.E. (2017). Peculiarities of quality management of teachers' e-learning training in the Arctic regions. Education, 38(55), 25.

Bradac, V., Walek, B.A. (2017). Comprehensive adaptive system for e-learning of foreign languages. Expert Systems with Applications, 90, 414-426.

Camilleri, P. (2017). Minding the gap. Proposing a teacher learning-training framework for the integration of robotics in primary schools. Informatics in Education, 16(2), 165-179.

Chernova, I.S., Korobkina, M.A. (2015). Analysis of concepts and various approaches to corporate training. Conference collections of works SIC Sociosphere, 6, 74-77.

Clark, R.C., Mayer, R. E. (2016). E-learning and the science of instruction: Proven guidelines for consumers and designers of multimedia learning. John Wiley \& Sons.

Corporate Training (n.d.). Retrieved from: http://www.e-xecutive.ru/wiki/index.php.

E-Soft Development. E-learning (n.d.). Retrieved from: http://www.web-learn.ru/bibliotekaonline/36-e-learning.

Global E-learning Market to Reach US\$107 Billion by 2015, According to New Report by Global Industry Analysts, Inc. (n.d.). Retrieved from: http://www.prweb.com/releases/distance_learning/e_learning/prweb9198652.htm?utm_ campaign=elearningindustry.com\&utm_source $=\% 2$ Felearning-statistics-and-facts-for2015\&utm_medium=link.

Jiang, Yu.H., Javaad, S.S., Golab, L. (2016). Data mining of undergraduate course evaluations. Informatics in Education, 15(1), 85-102.

Khagurov, T.A. (2012). On lifelong education. School Technologies, 4, 172-176.

Korobkina, M.A. (2013). Corporate personnel training. Study guide. Krasnodar: Kuban State University.

Kurucay, M., Inan, F.A. (2017). Examining the effects of learner-learner interactions on satisfaction and learning in an online undergraduate course. Computers and Education, 115, 20-37.

Marchuk, N.Yu. (2013). Psychological and pedagogical features of distance learning. Pedagogical Education in Russia, 4, 78-85.

Martin, S., Alvarez Valdivia, I.M. (2017). Students' feedback beliefs and anxiety in online foreign language oral tasks. International Journal of Educational Technology in Higher Education, 14, 18.

Min, Ch., Chiang, F.K., Jiang, Ya.N., Yu, Sh.Q. (2016). A context-adaptive teacher training model in a ubiquitous learning environment. Interactive Learning Environments, 25(1), 113-126.

Ouchi, W. (2017). Theory Z. Retrieved from: https://en.wikipedia.org/wiki/Theory_Z_of_Ouchi.

Overview of the World and Russian e-learning market (2016). Retrieved from: https://rakurs.spb.ru/2/0/3/1/?id=42.

Schulz, R., Isabwe, G.M., Reichert, F. (2014). Supporting teachers' needs within and through elearning systems. Proceedings of 2014 International Conference on Web and Open Access to Learning (ICWOAL). IEEE.

Skoulikari, A.I., Tsakalidis, A., Tsolis, D. (2015). Personalized and adaptive mobile e-learning for cultural education. Proceedings of 2015 Sixth International Conference on Information, Intelligence, Systems and Applications (IISA), IEEE.

Slobodsky, A.L. (2013). Training Personnel of Organizations. St. Petersburg: St. Petersburg State University of Economics.

Sorochinsky, M.A. (2016). Development of corporate e-learning. Modern Education: Traditions and Innovations, 4, 225-231. 
Vlasova, E.Z. (2014). E-learning in a modern university: Problems, prospects, and application experience. Universum: Bulletin of Herzen University, 1, 43-49.

Vlasova, E.Z., Barakhsanova, E.A., Goncharova, S., Aksyutin, P., Kuzin, Z.; Prokopyev, M.S. (2018). Effective adaptive training of students in Russian pedagogical universities to use e-learning technologies. Education, 39(23), 10.

Yang, C.Y., Chung, T.Y., Hwang, M.S., Li, C.Y., Yao, J.F.J. (2017). Learning Performance Evaluation in eLearning with the Web-Based Assessment. In Kim, K., Joukov, N. (eds). Information Science and Applications. ICISA 2017. Lecture Notes in Electrical Engineering, 424. Springer: Singapore. 